\title{
EFEKTIVITAS PENGELOLAAN DANA DESA (DD) TERHADAP KESEJAHTERAAN MASYARAKAT Studi Di Desa Atari Jaya Kecamatan Lalembuu Kabupaten Konawe Selatan
}

\author{
Nuning Fatimatuzzahro, Sulsalman Moita, Megawati Asrul Tawulo \\ Jurusan Ilmu Kesejahteraan Sosial, Fakultas Ilmu Sosial dan Ilmu Politik, \\ Universitas Halu Oleo, Kendari \\ e-mail: nuningfatimatuzzahro_kesos@gmail.com
}

\begin{abstract}
ABSTRAK
Penelitian ini bertujuan untuk menganalisis Efektifitas Pengelolaan Dana Desa (DD) Terhadap Kesejahteraan Masyarakat di Desa Atari Jaya Kecamatan Lalembu, Kabupaten Konwe Selatan, dan untuk mengetahui faktor yang menghambat dan pendukung Efektifitas Pengelolaan Dana Desa (DD) Terhadap Kesejahteraan Masyarakat di Desa Atari Jaya Kecamatan Lalembu, Kabupaten Konwe Selatan. Adapun metode penelitian yang digunakan yakni menggunakan metode penelitian Kualitatif, metode penelitian kualitatif adalah metode penelitian yang menghasilkan data deskriptif dari kata-kata tertulis atau lisan dari perilaku orang yang dapat diamati, teknik penelitian yang digunakan yaitu dengan cara observasi, wawancara, dan dokumentasi, adapun informan penelitian ini adalah aparat Desa 09 informan, warga setempat 04 informan, sehingga total informan semuanya berjumlah 13 informan. Adapun teknik analisis data yakni peneliti mengumpulkan seluruh data yang diperoleh baik dari hasil observasi, wawancara maupun dokumentasi, kemudian peneliti akan memilah dan memilih hasil data yang paling akurat mengenai fokus penelitian yang terkait. Kemudian setelah itu, peneliti melakukan pengolahan data, pengolahan data dimaksudkan untuk mencari temuan yang berkaitan dengan rumusan masalah yang dituliskan. Setelah peneliti melakukan pengolahan data untuk menjawab rumusan masalah, langkah selanjutnya adalah menuliskan atau menguraikannya kedalam bentuk laporan dengan kaidah-kaidah bahasa yang ada. Dari hasil penelitian yang dilakukan diperoleh, bahwa Efektifitas Pengelolaan Dana Desa (DD) Terhadap Kesejahteraan Masyarakat di Desa Atari Jaya Kecamatan Lalembu, Kabupaten Konwe Selatan yakni menggunakan tahapan-tahapan pengelolaan Dana Desa seperti peningkatan ketermpilam,peningkatan pendapatan,terpenuhnya kebutusan sosial ekonomi, peningkatan disverifikasi usaha kerja. Sedangkan faktor penghambat yaitu kepemimpinan, kebijakan, kelembagan, dan dan partisipasi masyarakat. faktor pendukungnya adalah memudahkan akses pemenuhan ekonomi khususnya petani yang ada di Desa Atari Jaya.
\end{abstract}




\section{WELVAART}

JURNAL ILMU KESEJAHTERAAN SOSIAL

Kata Kunci: Efektifitas, Pengelolaan, Dana, Desa, Terhadap, Kesejahteraan, Masyarakat

\section{PENDAHULUAN}

Pemberian otonomi daerah seluas luasnya berarti pemberian kewenangan dan keleluasaan (diskreksi) kepada daerah untuk mengelola dan memanfaatkan sumberdaya daerah secara optimal. Agar tidak terjadi penyimpangan dan penyelewengan, pemberian wewenang dan keleluasaan yang luas tersebut harus diikuti dengan pengawasan yang kuat. Meskipun titik berat otonomi diletakkan pada tingkat Kabupaten/Kota, namun secara esensi sebenarnya kemandirian tersebut harus dimulai dari level pemerintahan ditingkat paling bawah, yaitu Desa.

Selama ini, pembangunan desa masih banyak bergantung dari pendapatan asli desa dan swadaya masyarakat yang jumlah maupun sifatnya tidak dapat diprediksi. Adanya PP No.72 tahun 2005 dan di revisi UU No.6 tahun 2014 tentang Desa sangat jelas mengatur tentang pemerintahan Desa, yang menyatakan bahwa Desa adalah kesatuan masyarakat hukum yang meniliki batas-batas wilayah yang berwenang untuk mengatur dan mengurus kepentingan masyarakat setempat yang diakui dan dihormati dalam sistem pemerintahan Negara Kesatuan Republik Indonesia.

Landasan pemikiran dalam pengaturan mengenai desa adalah keanekaragaman, partisipasi, otonomi asli, demokratisasi dan pemberdayaan masyarakat. Pemerintahan desa berdasarkan UU No. 6 Tahun 2014 adalah penyelenggaraan urusan pemerintahan oleh Pemerintahan Desa dan Badan Permusyawaratan Desa dalam mengatur dan mengurus kepentingan masyarakat setempat berdasarkan asal-usul dan adat-istiadat setempat yang diakui dan dihormati dalam sistem Pemerintahan Negara Kesatuan Republik Indonesia.

Suatu kegiatan pemerintah desa, lebih jelasnya pemikiran ini didasarkan bahwa penyelenggaraan tata kelola desa (disingkat penyelenggaraan desa), atau yang dikenal selama ini sebagai "Pemerintahan Desa". Kepala Desa adalah pelaksana kebijakan sedangkan Badan Permusyawaratan Desa dan lembaga pembuat dan pengawas kebijakan (Peraturan Desa).

Pengelolaan keuangan desa menjadi wewenang desa yang dijabarkan dalam Peraturan Desa (Perdes) tentang anggaran dan pendapatan belanja desa (APBD). Dengan sumber pendapatan yang berasal dari pendapatan asli desa seperti hasil usaha desa, hasil swadaya dan partisipasi, hasil gotong royong dan lain-lain pendapatan asli desa yang sah.

Bergulirnya dana perimbangan melalui Dana Desa (DD) harus menjadikan desa benar-benar sejahterah. Untuk persoalan Dana Desa (DD) saja, meski telah diwajibkan untuk dianggarkan di pos APBD, namun lebih banyak daerah yang belum melakukannya.

Untuk itu, seharusnya proses transformasi kearah pemberdayaan desa terus dilaksanakan dan didorong semua elemen untuk menuju Otonomi Desa. Melihat jumlah anggaran yang diberikan kepada desa melalui Dana Desa tahun 2018 dengan anggaran mencapai Rp.646.081.000.00 untuk di Desa Atari Jaya, maka 


\section{WELVAART}

JURNAL ILMU KESEJAHTERAAN SOSIAL

muncul pertanyaan apakah desa beserta elemen yang ada sudah mampu melaksanakan pengelolaan anggaran tersebut secara baik.

Hal ini mengingat bahwa desa melaksanakan pembangunan hanya mendapat bantuan keuangan yang terbatas, jangka waktu penerimaan pun masih tersendat dan pengelolaannya masih sangat sentralistis oleh satuan instansi pemerintahan, dan Desa mendapatkan alokasi anggaran yang cukup besar dan pengelolaannya dilakukan secara mandiri, sehingga keraguan terhadap kemampuan Desa secara internal untuk mengelola dana desa tersebut masih dipertanyakan.

Pengelolaan Dana Desa di Desa atari jaya masih belum maksimal karna tersendatnya dana desa yang tutun di desa Atarai Jaya, tujuan dari Dana Desa (DD) ini adalah untuk membiayai program Pemerintah Desa dalam melaksanakan kegiatan pemerintah dan pemberdayaan masyarakat, sehingga pemerataan pendapatan, kesempatan bekerja dan kesempatan berusaha bagi masyarakat desa dapat ditingkatkan, Hal ini dikarenakan kurangnya pemberdayaan yang dilakukan kepada masyarakat.

Berdasarkan pertimbangan diharapkan keseluruhan Pemerintah desa dapat mengoptimalkan anggaran Dana Desa (DD) yang dimiliki sehingga penggunaan Dana Desa (DD) ini dapat menggerakkan roda perekonomian desa, maka pembangunan desa akan semakin meningkat. Pembangunan yang meningkat ini diharapkan akan mengurangi disparitas pertumbuhan antar desa. Berdasarkan latar belakang diatas, maka judul penelitian ini yaitu: ''Efektifitas Pengelolaan Dana Desa Terhadap Kesejahteraan Masyarakat Di Desa Atari Jaya Kecamatan Lalembuu Kabupaten Konawe Selatan”

\section{METODE PENELITIAN}

Penelitian ini telah dilaksanakan di Desa Atari Jaya Kecamatan Lalembuu Kabupaten Konawe Selatan. Alasan memilih lokasi penelitian ini karena sehubungan dengan dikucurkannya Dana Desa tahun 2018 sebagai upaya mensejahterakan masyarakat.

Informan penelitian ini adalah sebanyak 14 orang, yang terdiri dari Kepala Desa, Badan Permusyaratan Desa, Pendamping Desa, BumDes. Aparat Desa yang terdiri dari Sekretaris Desa, Bendahara Desa, Kasi pemerintahan, Kaur pelaksana pembangunan, Kepala Dusun dan ditambah dengan 5 (lima) orang masyarakat. Adapun teknik pengambilan sampel (informan) yakni secara sengaja (purposive sampling). Di mana yang menjadi informan dapat memberikan informasi sesuai dengan permasalahan penelitian.

Pengumpulan data merupakan suatu cara peneiliti untuk mengumpulkan data. Adapun tekhnik pengumpulan data yang akan dilakukan yakni :

1. Observasi

Observasi adalah teknik pengumpulan data yang dilakukan dengan cara mengamati atau melakukan pengamatan terhadap objek penelitian yang akan diteliti. 


\section{WELVAART}

\section{JURNAL ILMU KESEJAHTERAAN SOSIAL}

\section{Wawancara}

Wawancara merupakan teknik pengumpulan data/informasi melalui Tanya jawab secara langsung kepada informan.

\section{Dokumentasi}

Dokumentasi adalah teknik pengumpulan data berupa gambar, dokumendokumen, surat-surat, foto, laporan, buku catatan harian yang ada di lokasi penelitian.

Teknik analisis data dalam penelitian ini yakni :

Melakukan pemilihan dan penyusunan klasifikasi data, Melakukan penyuntingan data dan pemberian kode data untuk membangan kinerja analisis data, Melakukan konfirmasi data yang memerlukan verifikasi data dan pendalaman data, Melakukan analisis data sesuai dengan kontruksi pembahasan hasil penelitian, dan Setelah itu menuliskannya dalam bentuk laporan penelitian.

\section{PEMBAHASAN}

\section{Efektivitas Pengelolaan Dana Desa (DD) Terhadap Kesejahteraan Masyarakat Di Desa Atari Jaya Kecamatan Lalembuu Kabupaten Konawe Selatan}

Pengelolaan keuangan desa menurut peraturan pemerintah no 8 tahun 2016 Dalam peraturan tersebut memaknai bahwa efektifitas pengelolaan keuangan desa mulai dari peningkatan keterampilan, peningkatan pendapatan, terpenuhnya kebutuhan sosial ekonomi, peningkatan deskripikasi usaha kerja . Pengelolaan keuangan desa juga harus dilakukan berdasarkan tata kelola pemerintahan yang baik (Good Governoance), Pemerintah desa tidak akan kuat dan otonomi tidak akan bermanfaat bagi masyarakat jika tidak ditopang.

\section{a. Peningkatan Keterampilan}

Proses peningkatan keterampilan harus dilakukan berdasarkan program, skala prioritas, agenda kegiatan dan terdapat outcome yang jelas dari masingmasing kegiatan. Peningkatan keterampilan oleh pemerintah desa atari jaya adalah untuk meningkatkan dan menambah pengetahuan masyarakat dalam berdaya saing untuk bagaimana bisa meningkatkan kualitas SDM masyarakat sendiri agar tidak tergantung dari orang lain dan dengan cara ini masyarakat bisa menambah pengetahuan dalam bidang pupuk organik serta tidak menuntut kemungkinan masyarakat bisa mendirikan industri sendiri untuk pupuk organik. Hal itu juga selaras mandate dari pemerintah pusat untuk meningkatkan keterampilan masyarakat. Jadi masyarakat bisa meningkatkan pertanian dengan pupuk yang dipelajari tersebut.

\section{b. Peningkatan Pendapatan}

Program pembangunan dan pemberdayaan masyarakat melalui DD (dana desa) yang dilakukan baik melalui kebijakan nasional maupun daerah berupaya untuk menjadikan masyarakat diberdayakan sehingga meningkatkan pendapatan 


\section{WELVAART}

JURNAL ILMU KESEJAHTERAAN SOSIAL

masyarakat. Seluruh penerimaan dan pengeluaran desa yang dilakukan oleh pemerintah desa dilaksanakan untuk kesejahteraan sosial ekonomi masyarakat desa tersebut.

kebijakan-kebijakan yang dirumuskan oleh pemerintah desa Atari jaya dan masyarakat harus mengedepankan visi jangka panjang yang dibutuhkan untuk pembangunan peningkatkan perekonomian. Dengan adanya kebijakan tersebut, maka masyarakat yang terdapat di desa atari jaya akan memiliki kesempatan untuk menerima lebih maju dan meningkatkan pendapatan perekonomian. Hal tersebut selaras dengan tujuan pemerintah pusat dan menanggulangi pengangguran dan kemiskinan di pedesaan. Namun, tidak menutup kemungkinan dari setiap pelaksanaan dilapangan tidak ada kendala pasti ada kendala namun masih bisa tertutupi.

\section{c. Terpenuhinya Kebutuhan Sosial dan Ekonomi}

Dalam pengelolaan keuangan desa, Pemerintah desa wajib memenuhi kebutuan sosial dan ekonomi masyarakat desa. Dengan terpenuhinya kebutuhan tersebut dapat meningkatkan taraf hidup masyarakat agar desa tersebut bisa terangkat menjadi desa berkembang dan kalau perlu bisa memperoleh hak menjadi kelurahan.

Adapun penggunaan dana desa untuk terpenuhinya kebutuhan sodian dan ekonomi pemerintah desa mengadakan pengadaan bibit tanaman keras/kelapa gajah nias, insentif imam masjid, insentif pemangku adat, insentif kader posyandu, insentif guru TK, Insentif kader pengajar pend.Agama. Dengan bgitu pemerintah desa Atari Jaya telah melakukan peningkatan terpenuhnya kebutuhan sosial dan ekonomi agar untuk meningkatkan kesejahteran masyarakan dengan adanya Dana Desa.

\section{d. Peningkatan Disverifikasi Usaha Kerja}

Dalam peningkatan disverifikasi usaha kerja pemerintah Desa Atari Jaya melalui BUMdes telah menjalakan usaha sosial/serving, bisnis penyewaan, perdagangan, usaha bersama/hoding, dll. Dengan tujuan meningkatkan taraf hidup masyarakat serta membantu masyarakan agar bisa berwirausaha. Hal ini sesuai dengan Undang-Undang no 6 tahun 2014 tentang desa yaitu "melalui BUMdes masyarakat dapat membangun usaha kerja sendiri dengan di bantu dana desa melalui BUMdes. Peraturan Daerah tersebut dimaksudkan untuk memberikan landasan hukum bidang keuangan desa, sumber keuangan desa, pengelolaan keuangan desa, dan anggaran pendapatan dan belanja desa. untuk pengelolaan administrasi keuangan.

\section{Faktor-Faktor Yang Mempengaruhi Efektivitas Pengelolaan Dana Desa}

Faktor-faktor yang mempengaruhi pemerintah Desa Atari Jaya dalam pengelolaan dana desa dapat diidentifikasi melalui hasil wawancara langsung dengan pemerintah Desa atari jaya sebagai instansi yang bertugas sebagai 


\section{WELVAART \\ JURNAL ILMU KESEJAHTERAAN SOSIAL}

pelaksana pengelolaan dana desa, sampai pada tahap evaluasi dan pelaporan pengelolaan dana desa.

Baik Pemerintah Desa atari jaya maupun masyarakat desa mengemukakan berbagai faktor yang menjadi penghambat yang efektifitas dalam pengelolaan Dana Desa adalah sebagai berikut.

\section{a. Kepemimpinan}

Kepemimpinan adalah aktifitas mempengaruhi orang-orang supaya diarahkan mencapai tujuan organisasi. Kepemimpinan yang dimaksud disini yaitu kemampuan pemerintah desa dalam mengelola Dana Desa, secara lebih khusus kemampuan Kepala Desa dalam mempengaruhi bawahannya dalam mengelola dana desa yang di peroleh dari APBdesa.

Di bawah kepemimpinan bapak Zakaria selaku kepala desa atari jaya bahwa selama beliau menjabat sebagai kepala desa dan menjalankan tugas sebagai pimpinan desa Atari Jaya sangat baik, masyarakat dan perangkat desa merasa senang dan bahagia sebab kepemimpinan kepala desa mengedepankan dari kebutuhan-kebutuhan untuk kesejahteraan masyarakat, tapi satu hal yang membuat masyarakat kurang senang yaitu dengan menempatkan struktur perangkat desa yang kebanyakan dari garis keluaranya sendiri.

\section{b. Kebijakan Pemerintah}

Kebijakan adalah serangkaian tindakan yang mempunyai tujuan tertentu yang mesti di ikuti dan dilakukan oleh para pelakunya untuk memecah sesuatu masalah. Kebijakan yang dimaksud disini adalah kebijakan kepala desa dalam menjalankan wewenangnya seebagai kepala desa dalam mencapai kesejahteraan masyarakat desa Atari Jaya

Berdasarkan hasil penelitian yang dilakukan peneliti, bahwa kepala desa dalam menjalankan tugas sebagai pimpinan desa Atari Jaya, masyarakat dan perangkat desa merasa senang dan bahagia sebab kepemimpinan kepala desa mengedepankan dari kebutuhan kebutuhan untuk kesejahteraan masyarakat, tapi satu hal yang membuat masyarakat kurang senang yaitu dengan menempatkan struktur perangkat desa yang kebanyakan dari garis keluaranya sendiri.

\section{c. Kebijakan Pemerintah}

Kebijakan adalah serangkaian tindakan yang mempunyai tujuan tertentu yang mesti di ikuti dan dilakukan oleh para pelakunya untuk memecah sesuatu masalah. Kebijakan yang dimaksud disini adalah kebijakan kepala desa dalam menjalankan wewenangnya seebagai kepala desa dalam mencapai kesejahteraan masyarakat desa Atari Jaya.

Berdasarkan hasil penelitian yang dilakukan peneliti, bahwa kepala desa dalam mengambil kebijakan dalam pengelelolaan APBDesa selalunya diawali dengan musyawarah mufakat. Dari kepala desa, perangkat desa BPD, tokoh tokoh masyarakat dan warga msyarakat selalunya melakukan rapat sebelum membangun dan jika misalkan dalam pembangun itu bermasalah, maka pemerintah desa juga 


\section{WELVAART}

\section{JURNAL ILMU KESEJAHTERAAN SOSIAL}

selalunya mengefaluasi. Dalam hal ini pemerintah melihat kesejahteraan masyaakat berdasarkan musyawarah dan mufakat.

\section{d. Kelembagaan}

Kelembaga adalah badan, organisasi, kaidah, dan norma-norma baik formal maupun informal sebagai pedoman untuk mengatur perilaku segenap anggota masyarakat baik dalam kegiatan sehari-sehari maupun dalam usahanya mencapai suatu tujuan tertentu .

Dari hasil wawancara diatas dapat disimpulkan bahwa desa Atari jaya memiliki Dua lembaga besar dalam Desa tersebut untuk menjalankan roda organisasi dalam membahas APBDesa selalunya melibatkan anggota legislatif desa tersebut.

\section{e. Partisipasi Masyarakat}

Partisipasi adalah keikut sertaan masyarakat dalam mengelola dan membangun desa untuk mencapai desa yang mandiri. Yang di bahas disini adalah partisipasi masyarakat Desa Atari jaya dalam keikut sertaan dalam membangun desa tersebut. Melalui wawancara dari beberapa pihak antara lain

Dari pernyatan diatas dapat disimpulkan bahwa dalam partisipasi masyarakat itu ada, misalkan partisipasinya dengan pemikiran. Dalam partisipasi pembangunan desa masyarakat ikut serta di berdayakan dengan cara memberikan pekerjaan dengan diberi upah sebagai pembantu kontraktor. kalau hanya bekerja dalam membangun desa tanpa di beri imbalan apapun tentu masyarakat tidak ada yang ikut berpartisipasi.

\section{KESIMPULAN}

Hasil dari penelitian pengelolaan Dana Desa yang dilakukan oleh pemerintah desa Atari jaya Kecamatan Lalembuu Kabupaten Konawe Selatan, dapat disimpulkan sebagai berikut:

1) Pengelolaan keuangan Dana Desa yang diterapkan oleh pemerintah desa Atari Jaya sudah sesuai dengan perundang-undangan maupun ketentuanketentuan yang berlaku. Kepala desa beserta jajarannya telah melakukan pembangunan fisik maupun pembangunan non fisik dengan tujuan untuk meningkatkan Ekonomi masyarakat untuk mencapai desa yang mandiri.

Pengelolaan Dana Desa dalam meningkatkan pembangunan non fisik dengan melakukan pelatihann/ peningkatan keterampilan telah di lakukan oleh pemerintah desa dalam mewujudkan masyarakat yang berpengetahuan untuk mendorong masyarakat yang mandiri, Adanya pemanfaatan Dana Desa dalam pembangunan fisik dengan membangun jalan tani dan jalan dusun meningkatkan pendapatan masyarakat melalui pendapatanpertanian, Melalui anggaran Dana Desa menjadikan masyarakat mendapatkan insentif- insentif lebih dan bantuan bibit-bibit tanaman pertanian memenuhi kebutuhan sosial dan ekonomi, dan 
Dengan BUMDesa masyarakat Desa Atari Jaya dapat membangun usaha kerja kerja sendiri dengan bantuan dari dana BUMDesa.

2) Adapun faktor yang mempengaruhi efektifitas pengelolaan dana desa yaitu: Pengeluaran dana desa yang bertahap akhirnya pembangunan tidak bisa terselesaikan dalam jangka waktu yang cepat, dan Adanya pertikaain dalam kalangan masyarakat yang kurang setuju dengan pembangunan yang telah di rapatka ada kalangan masyarakat yang menginginkan pembangunan lain dalam pemanfaatan dana desa.

\section{DAFTAR PUSTAKA}

Andi Saputra I Wayan .2014.Efektivitas Pengelolaan alokasi dana Desa Pada Desa Lambean Kecamatan Kintamani Kabupaten Bangli.Jurnal Pendidikan Ekonomi

Haris, Dian Rasdiyanah, 2015. Efektivitas Pengelolaan Zakat,Infaq dan Sedekah pada Badan Amil Zakat Nasional Kota Kendari. Skripsi, Fakultas Ekonomi, Universitas Halu Oleo.

Soetomo, 2014, kesejahteraan dan Upaya Mewujudkannya dalam perspektif Mayarakat Lokal. Yogyakarta: Penerbit Pustaka Pelajar.

\section{Peraturan Perundang-Undangan}

Peraturan Pemerintah No 8 Tahun 2016 Tentang Efektifitas Pengelolaan Keuangan Desa

Undang-Undang Nomor 6 Tahun 2014 tentang Desa

UU No 6 tahun 2014 menjelaskan semua hak dan kewajiban desa

Undang-Undang Pemerinth Daerah N0 32 Tahun 2014 Tenang Desa 